\title{
1788-1825 (Hicrî 1203-1240) Dönemine Ait Bir İcmâl Defterine Göre Darphanenin Maden Temin ve Sikke Darp Faaliyeti
}

\author{
Ömerül Faruk Bölükbaşı
}

\section{Özet}

Bu çalışmada 1788-1825 yılları arasına ait bir icmâl defterine istinaden Osmanlı para ve madencilik tarihine dair birtakım değerlendirmeler yapılacaktır. Mevzubahis defterde darphaneye madenlerden gelen gümüş miktarı, bu gümüşten sikke basımı ve darphanenin piyasadan satın aldığı altından para basarak elde ettiği gelir hakkında bilgi verilmektedir. Bu bilgiler arşiv belgeleri ve literatürle desteklendiğinde özgün sonuçlar ortaya çıkmaktadır. Bunlardan ilki Osmanlı madenlerinde gümüş üretiminin bu dönemde büyük bir düşüş yaşadığı, ikincisi ise bu dönemde yaşanan malî krizin aşılmasında altın sikke basımından elde edilen gelirin önemli bir rolü olduğudur. Literatürde Osmanlı madenlerinin üretim rakamlarına dair var olan bilgiler yetersizdir ve düzenli bir istatistiki seri oluşturmaktan uzaktır. Ayrıca söz konusu dönemde yaşanan malî krizin gümüş sikkelerin tağşişiyle aşıldığı hususuna vurgu yapılmaktadır. İcmâl defterinin verdiği bilgiler, Osmanlı madenlerinin gümüş üretimine dair otuz altı yıllık düzenli bir seri oluşturmakta; malî krizin aşılmasında gümüş sikkeler kadar olmasa da, altın sikkeler üzerinde yapılan ayarlamaların da önemli katkısı olduğunu ortaya koymaktadır.

Anahtar Kelimeler: Cihâdiye, rûmî altını, adlî altını, darp faizi, tağşiş, gümüş üretimi, Sultan II. Mahmud

\section{Mine Procurement and Specie Coinage Activities According to an Icmâl Book Pertaining to the Period between 1788-1825 (H. 1203-} 1240)

\section{Abstract}

We try to make an evaluation of Ottoman monetary and mining history according to an icmâl book pertaining to period between the years 17881825. Some information is provided regarding the amount of silver coming

\footnotetext{
* Yrd. Doç. Dr., Bilecik Şeyh Edebali Üniversitesi, Fen-Edebiyat Fakültesi, Tarih Bölümü, faruk.bolukbasi@bilecik.edu.tr. (Makale gönderim tarihi: 2016-03-06; makale kabul tarihi: 2016-03-24)
}

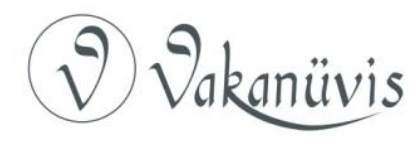


from mines to the Mint, specie coinage and the revenue obtained through money coinage with gold bought from the market in this icmâl book. Original results are obtained when this information is transformed into tables and graphics and supported by archival documents and literature. First of these results is that silver production in Ottoman mines experienced a dramatic decrease in that period and the second is that revenue obtained from gold specie coinage was very influential in overcoming the financial crisis in that period. Information in the literature regarding the amount of production in Ottoman mines is insufficient and is far from making up a regular statistical series. Besides, we emphasize the fact that financial crisis in that period is overcome by debasement of silver species. The information in icmâl book makes up a regular series of thirty six years regarding the silver production in Ottoman mines; and reveals that adjustments on gold species was very influential in overcoming financial crisis even if not influential as the ones on silver species.

Keywords: cihâdiye coin, rûmî gold coin, adlî gold coin, seigniorage, debasement, silver production, Sultan Mahmud II.

\section{Giriş}

Osmanlı tarihi araştırmaları kantitatif verilerin derlenmesi ve uzun vadeli istatistiki serilerin inşası konusunda henüz yeterli seviyeye ulaşamamıştır. Arşivler gerekli malzeme konusunda zengin olmasına rağmen nüfus, ziraî ve sınaî üretim, eğitim, bütçe, fiyat, ücret gibi konularda çalışmalar az sayıdadır ${ }^{1}$. Osmanlı tarihçiliğinin kantitatif verilerin yetersizliğiyle mâlûl alanlarından biri de para tarihi araştırmalarıdır. Darphanelerin maden temin ve sikke darp faaliyeti, para basım geliri, Osmanlı piyasasında tedavül eden yerli ve yabancı sikkelerin kurları gibi temel hususlarda çeşitli istatistiki çalışmalar mevcutsa da sayıları oldukça sınırıdır². Konuyla ilgili evrakın büyük

${ }^{1}$ Bu konuda yapılan çalışmalardan bazıları şunlardır: Mehmet Genç, Erol Özvar, Osmanlı Maliyesi: Kurumlar ve Bütçeler, İstanbul 2006; Şevket Pamuk, XIX. Yüzyılda Osmanlı Dış Ticareti, Tarihi Istatistikler Dizisi I, Ankara 1995; Cem Behar, Osmanlı imparatorluğu'nun ve Türkiye'nin Nüfusu 1500-1927, Tarihi istatistikler Dizisi II, Ankara 1996; Tevfik Güran, Osmanlı Tarım Istatistikleri 1909, 1913 ve 1914, Tarihi Istatistikler Dizisi III, Ankara 1997.

${ }^{2}$ Bu konudaki çalışmalardan bazıları şunlardır: Halil Sahillioğlu, Bir Asırlık Osmanlı Para Tarihi, 1640-1740, İstanbul Üniversitesi İktisat Fakültesi, Basılmamış Doçentlik Tezi, İstanbul 1965; Şevket Pamuk, Osmanlı Imparatorluğu'nda Paranın Tarihi, İstanbul

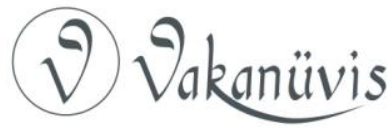


oranda perakende olması, derlenmesinin çetin bir mesai gerektirmesi, kayıtların çok mufassal olması nedeniyle değerlendirmenin uzun zaman alması, bu sahadaki çalışmaların başlıca engelleridir. Bir aylık emisyon rakamını veya temin edilen maden miktarın belirlemek için bile çok sayıda defteri incelemek ve uzun hesaplamalar yapmak gerekmektedir ${ }^{3}$.

Bu çalışmada literatürdeki boşluğun doldurulmasına kısmen de olsa katkı sağlayabilecek bazı veriler ortaya konulacaktır. Söz konusu veriler darphaneyle ilgili bir icmâl defterine dayanmaktadır. Muhtemelen üst makamları bilgilendirmek için hazırlanmış olan bu icmâl, beş sayfalık kısa bir defter olmasına rağmen sağladığı bilgilerin keyfiyeti bir hayli yüksektir ${ }^{4}$. Defterin ihtiva ettiği hususlardan ilki 1788-1824 yılları arasında darphaneye madenlerden gelen gümüş ve bundan basılan sikkeler hakkındadır. íkincisi ise 1788-1825 yılları arasında piyasadan satın alınan altından sikke basılmasıyla elde edilen gelire dairdir. Defterde sunulan veriler sayesinde bu dönemde basılan bazı sikkelerin vezin ve ayarının tespiti de mümkündür. Bilindiği üzere XVIII. yüzyılın sonlarında başlayan ve 1844 yılındaki Tashih-i Sikke ıslahatına kadar devam eden dönem, malî ve ekonomik kriz nedeniyle tağşişlerin zirveye çıktığı, para sisteminin buhrana girdiği bir süreçtir. Bu nedenle döneme ait darphane evrakı büyük çeşitlilik arz etmekte ve sayısal olarak devasa bir yekuna baliğ olmaktadır. Böyle bir dönemde bahsi geçen icmâl defterindeki gibi derli toplu veriler bulabilmek oldukça güçtür ${ }^{5}$.

İcmâl defterindeki veriler çok kıymetli olmasına rağmen bazı eksiklikleri yüzünden ikmâl ve tasrihe muhtaçtır. Illk olarak izahı

1999; Ömerül Faruk Bölükbaşı, XVIII. Yüzyılın ikinci Yarısında Darbhâne-i Âmire, İstanbul 2013; "Osmanlı Taşra Darphaneleri (1697-1758)" Türk Kültürü Incelemeleri Dergisi, 29, İstanbul 2013, 27-76.

${ }^{3}$ Bu konuda fikir vermesi için künyeleri verilen arşiv evrakına bakılabilir: D.DRB.d, nr. 1151; HH.d, nr. 16784; 19612; 19613.

${ }^{4}$ Arşiv künyesi HH.d, nr. 15352 olan bu defter, Hicrî 1203 yılı Muharrem ayı ile 1240 yılı Receb ayı arasındaki döneme ait bilgiler içermektedir. Bu tarihler ise Ekim 1788 ile Mart 1825 arasına tekâbül etmektedir.

${ }^{5}$ Dönemin şartları ve para sisteminin içinde bulunduğu durum için bakınız: Şevket Pamuk, "En Büyük Tağşiş, 1808-1844" Osmanlı Ekonomisi ve Kurumları, Seçme Eserler I, İstanbul 2007, s. 123-131; Bölükbaşı, Darbhâne-i Âmire, s. 125-132.

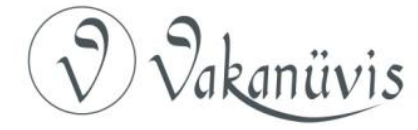


gereken husus maden ocaklarından gelen gümüşten basılan sikkelerin hangi tarihlerde basıldığı meselesidir. Defterde darp edilen sikke cinsleri sırayla verilmiş olmasına rağmen, bunların ne zaman basıldığı hususunda bilgi yoktur. Altın sikke darbından elde edilen gelirde ise iniş çıkışlar vardır. Eklerde yer alan tablo ve grafikler incelendiğinde görüleceği üzere bazen bir önceki yııın beş-altı katı artışlar yaşanmıştır. $\mathrm{Bu}$ iniş çıkışların ve darp gelirinde bu kadar büyük artışların nasıl sağlanabildiğinin izah edilmesi gerekmektedir. Öte yandan defterde veriler kuruş cinsinden kaydedilmiştir. Devir tağşişlerin yoğun olduğu bir dönem olduğu için rakamların reel karşılığına dair açıklamalar yapılmalıdır. Ayrıca defterde darp faizi verilmekte basılan toplam altın miktarı gösterilmemektedir. Bu konuda da eldeki verileri daha anlamlı kılabilecek bazı değerlendirmeler gerekmektedir. Ayrıca defter sayesinde ulaşılan ve literatürdeki bilgileri değiştiren sonuçların altının çizilmesi de büyük önem taşımaktadır.

İcmâl defterinin kapsadığı devir, Osmanlı para sisteminin en sıkıntılı dönemlerinden birine denk gelmektedir. Aslında XVII. yüzyıl sonlarında Avrupa standardında iri gümüş sikkeler basılmaya başlanması ve darphanenin teknik açıdan modernize edilmesi, Osmanlı para sistemini sağlıklı bir zemine kavuşturmuştu. XVIII. yüzyılın ilk altmış yılında siyasî istikrarın sürmesi Osmanlı para düzeninin de sorunsuz işlemesini sağlamıştı. Bu süreçte sisteminin temel taşı ve saygınlığının sembolü gümüş kuruştu. Ancak 1768-1774 yılları arasında Ruslarla yapılan savaşın büyük bir felaketle sonuçlanması siyasî bir buhrana yol açtığı gibi, iktisadî ve malî krize de sebebiyet vermiştir. Bu tarihten sonra savaşların bir türlü sonunun gelmemesi hazinenin bütün kaynaklarını tüketmiştir. Dış borçlanma imkânının bulunamaması, iç borç temininin yetersiz ve çok yüksek mâliyetli olması tağşişleri mecburiyet haline getirmiştir. Finansman baskıları nedeniyle kuruş, selefi akçenin akıbetine uğramış, sürecin sonunda gümüş içeriğini büyük oranda yitirmiştir. Bilindiği üzere tağşiş sikkenin içerdiği kıymetli maden miktarının azaltılmasıydı.

${ }^{6}$ Osmanlı para tarihinin ana hatları için bakınız: Halil Sahillioğlu, "Osmanlı Para Tarihinde Dünya Para ve Maden Hareketlerinin Yeri 1300-1750" Orta Doğu Teknik Üniversitesi Geliştirme Dergisi:1978 Özel Sayısı, Ankara, 1978, s. 2-93; Şevket Pamuk, “Osmanlı İmparatorluğu'nda Para, 1326-1914" Osmanlı Imparatorlu-ğu'nun Ekonomik

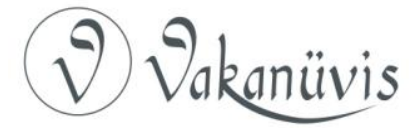


XVIII. yüzyılın başlarında kuruş $\% 60$ ayarında ve 26,457 gram vezindeydi. Saf gümüş içeriği ise 15,874 gramdı. 1758 yılına gelindiğinde ise vezni 24,052 , gümüş içeriği ise 14,431 grama inmişti. Ayarında herhangi bir değişikliğe gidilmemişti. Yaklaşık altmış yıllık süreçte gümüş içeriğinde yaşanan kayıp \%10 civarındaydı. Bu oran tolere edilebilir bir seviyedeydi ve çeşitli tarihlerde yapılan bazı küçük ayarlamalardan kaynaklanıyordu. Ancak 1758 yılında ve takip eden süreçte büyük tağşişler yapılmış, 1787-1792 Osmanlı-Rus Savaşı sırasında ise o zamana kadar yapılan en büyük iki tağşiş gerçekleştirilmiştir. 1789 yılı Eylül ayında 2,5 kuruş değerindeki yüzlüklerin darbıyla birlikte kuruşun ayarı $\% 51$; vezni 12,828 ; gümüş içeriği ise 6,542 gram olmuştur. Böylece kuruş başlangıçtaki gümüş içeriğinin \% 60'a yakınını kaybetmiştir. Bu tağşişten sonra III. Selimin saltanatı döneminde yeni bir ayarlamaya gidilmemiştir ${ }^{7}$. Ancak II. Mahmud döneminde tağşişler tekrar başlamış, özellikle 1820'li yıllardan itibaren hız kazanmıştır. Şevket Pamuk'un hesaplamalarına göre kuruşun gümüş içeriği 1844 yılındaki Tashih-i Ayar öncesinde 0,94 grama kadar düşmüştü. Bu da ilk ortaya çıktığı dönemden Tashih-i Ayar'a kadar kuruşun gümüş içeriğinin yaklaşık \% 95'ini kaybettiğini gösterir ${ }^{8}$.

\section{Maden Ocaklarından Darphaneye Gelen Gümüş ve Bundan Sikke Darbı (1788-1824)}

Sikke basarken darphaneyi besleyen asıl kaynak piyasaydı. Ticaret yoları üzerinde önemli bir konuma sahip olan Osmanlı Devleti, çok miktarda yabancı sikkenin tedavül ettiği canlı bir piyasaya sahipti. Bu durum darphanenin hammadde teminini kolaylaştırıyordu. Ancak piyasadan temin edilen sikkelerden para basmak düşük oranda gelir

ve Sosyal Tarihi, 1600-1914, ed. Halil İnalcık, Donald Quataert, çeviren: Serdar Alper, İstanbul 2004, II, 1053-1093. Kuruşun uğradığı tağşişler için bakınız: Pamuk, En Büyük Tağşiş, s. 123-131; Bölükbaşı, Darbhâne-i Âmire, s. 125-132.

${ }^{7}$ Bölükbaşı, Darbhâne-i Âmire, s. 125-132.

${ }^{8}$ Pamuk, En Büyük Tağşiş, s. 131.

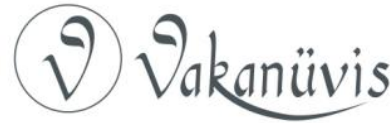


getiriyordu. Maden ocaklarından gelen altın ve gümüşün miktarı sınırlı olmakla birlikte, para basıldığında yüksek oranda kâr bırakıyordu?

Devlet ricali darphanenin para basımını sürdürebilmesine hayatî derecede önem veriyordu. Bu amaçla herhangi bir aksama olmadan, mümkün olan en yüksek miktarda ve en düşük mâliyetle maden temini için gerekli tedbirler alınmıştı. Daha açık bir ifadeyle altın ve gümüş piyasası üzerinde darphane lehine bir tekel oluşturulmuştu. Maden ocaklarında istihsal edilen kıymetli madenin tamamına yakını darphaneye geliyor, üretimleri altın ve gümüşe dayanan esnafa hammaddelerini darphane veriyordu ${ }^{10}$. Kıymetli maden piyasasında darphanenin ayrıcalıklı konumu düşünülürse, maden ocaklarından darphaneye gelen gümüş miktarının, aynı zamanda maden ocaklarında üretilen gümüşün miktarını gösterdiği de söylenebilir.

İcmâl defterine göre Hicrî 1203-1239 (Miladî 1788-1824) yılları arasında maden ocaklarından darphaneye 159 ton civarında gümüş gelmiştir. Bu rakamı ocakların toplam üretim miktarı olarak da kabul edebiliriz. Gümüş üretiminin kronolojik seyri takip edildiğinde, bazı yıllar artış olsa da, genel eğilimin düşüş yönünde olduğu görülür. III. Selim'in ilk yıllarında 8,5 tonu gören yıllık üretim, 1820'li yıllarda 2-2,5 ton civarına düşmüştü. Dönem ortalaması ise 4,5 tona yakındı ${ }^{11}$. 1730 'lı yıllarda madenlerdeki yıllık gümüş üretiminin 25 ilâ 40 ton arasında değiştiğini biliyoruz ${ }^{12}$. Bu durum yaklaşık bir asır zarfında Osmanlı madenlerinin gümüş istihsalinde muazzam bir azalma olduğunu ortaya koyar.

\footnotetext{
${ }^{9}$ Mesela Hicrî 1179 yılı Şevval ayında (Miladî 1766 Mart-Nisan) darphanede basılan 543.203 kuruşun sadece 57.016 kuruşu maden ocaklarından gelen gümüşten basılmıştı. Kalan kısmı yani 486.187 kuruşu piyasadan toplanan eski ve yabancı paralar eritilerek darp edilmişti. Darphane maden ocaklarından gelen gümüşten \%48 oranında, yani $27.494,5$ kuruş kâr elde etmişti. Piyasadan toplanan gümüşün bıraktığı kâr ise \%9'u bile bulmuyordu (D.BŞM.DRB.d, nr. 16641).

${ }^{10}$ Bu kısımda verilen bilgiler daha çok XVII. yüzyılın sonlarından Tanzimat Fermanı'na (1839) kadar olan dönem için geçerlidir (Bölükbaşı, Darbhâne-i Âmire, s. 69-105; 113125).

${ }^{11}$ Defterde Hicrî 1221 (Miladî 1806-1807) yılı darphaneye maden sevki olmadığını gösteren "fıkdan" ifadesiyle boş geçilmiştir. Ayrıca Hicrî 1223-1239 (Miladî 1808-1824) yılları arasındaki toplamdan 797.587,314 gramlık gümüş "mevkuf" ifadesiyle düşülmüştür (HH.d, nr. 15352, vr. 1b-2a; Tablo I; Grafik I).

${ }^{12}$ Pamuk, Paranın Tarihi, s. 177.
} 
Darphaneye gelen maden miktarının yıllık seyri konusunda ayrıntılı bilgi veren defter, hangi maden ocağından ne kadar gümüş geldiği konusunda ise ketum davranmaktadır. Defterde sadece Hicrî 1203 (Miladî 1788-1789) yılına ait üretimin maden ocaklarına göre dökümü yapılmaktadır. Buna göre darphaneye Keban, Gümüşhane, Sidrekapsi, Bozkır ve Kratova madenlerinden gümüş gelmekteydi. En fazla üretimi \%85'i aşan oranıyla Keban madeni yapmakta, diğer ocaklarda yapılan üretim ise oldukça düşük seviyelerde kalmaktaydı ${ }^{13}$.

Maden ocaklarında üretilen 159 ton civarındaki gümüşten hangi paraların darp edildiği de gayet önemlidir. Ancak defterde darp faaliyeti her yıl için müstakil olarak verilmek yerine, basılan para türlerine göre toplu olarak gösterilmiştir. Emisyon rakamlarını yıllık olarak tespit etmek mümkün değilse de, başka kaynaklardan edinilen bilgilerle hangi sikkenin hangi dönemde basıldığı veya basılmaya başlandığı belirlenebilmektedir. Bu dönemde büyük tağşişler gerçekleştiği için basılan para miktarının reel olarak ne ifade ettiğinin tespit edilmesi gerektiği de söylenebilir. Ancak basılan para miktarı yıllık bazda verilmediği için nominal değerlerin reel değerlere dönüştürülmesi mümkün değildir. Zaten basılan her sikke türü için ne kadar gümüş kullanıldığı bilindiğinden bu sorun önemini yitirmektedir ${ }^{14}$.

Hicrî 1203-1222 (Miladî 1788-1808) yılları arasında maden ocaklarından darphaneye gönderilen 105 ton civarındaki gümüşten 14.913.952 kuruş basılmış, 7.338.820,5 kuruş gelir elde edilmişti. Gümüşün bir dirheminin darphaneye maliyeti 27 akçeydi. Bu rakam piyasa fiyatının oldukça altında bir bedele tekâbül ettiği için \%49 oranında kâr sağlanmıştı. Basılan kuruşlar \%51 ayarında, 4 dirhem veznindeydi ${ }^{15}$. Bu veriler literatürdeki Sultan III. Selim'in saltanatının ilk aylarında, Eylül 1789 'da yapılan tağşişten sonra herhangi bir tağşişe gidilmediği yönündeki bilgileri teyit eder ${ }^{16}$.

\footnotetext{
${ }^{13} H$ H.d, nr. 15352, vr. $1 b$.

${ }^{14}$ HH.d, nr. 15352, vr. 1b, 2a; Tablo II.

${ }^{15}$ HH.d, nr. 15352, vr. 1b; Tablo II.

${ }^{16}$ Pamuk, En Büyük Tağşiş, s. 131; Pamuk, Paranın Tarihi, s. 178; Bölükbaşı, Darbhâne-i Âmire, s. 132.
}

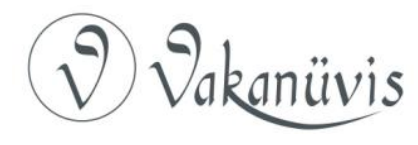


Hicrî 1223-1239 (Miladî 1808-1824) yılları arasında ise maden ocaklarından darphaneye 54 ton civarında gümüş gelmiş, bundan çeşitli vezin ve ayarda sikkeler basılmıştı. Bunlardan ilki oldukça mânidar bir isme sahip olan ve askerî masrafların karşılanması için darp edilen cihâdiyeydi. Bin bir türlü iç ve dış gailenin gölgesi altında saltanat sürmek zorunda kalan Sultan II. Mahmud, tağşişlerin halk arasında yol açabileceği tepkiyi azaltmak için bu adı özellikle tercih etmiş olmalıdır. Daha sonra bunlar atik beşlik olarak da anılmıştır. Vezni 8 dirhem, ayarı \% 80 olan cihâdiyeler 5 kuruş değerindeydi. Literatürde cihâdiyenin ayarı \%73 olarak gösterilmektedir. Ancak icmâl defterindeki rakamlar üzerinden hesaplama yapıldığında doğrusunun \%80 olduğu görülür. Üstelik bu bilgiyi başka arşiv belgeleri de teyit eder. Cihâdiye basılırken kullanılan gümüşün bir dirheminin maliyeti 33 akçeydi. Bu dönemde basılan cihâdiye miktarı 579.753,5 adetti. Bu miktarda cihâdiye 2.898.766,5 kuruşa tekâbül ediyordu. Bundan elde edilen gelir ise 1.779.226 kuruştu ${ }^{17}$.

Cihâdiye basım kararının alındığı şûrada, beş kuruş (200 pâre) değerindeki yeni sikkenin 100 pâre değerinde yarısının, 50 pâre değerinde çeyreğinin, 25 pâre değerinde sekizde birinin basılması hususunda görüş birliği oluşmuş, ardından kamuoyuna ilan edilmişti. Ancak daha sonra bu durumun çeşitli mahzurlara yol açacağı düşünülerek, çeyreğinin ve sekizde birinin basımından vazgeçilmişti. Dolayısıyla sadece tam (200 pârelik), yarım (100 pârelik) ve onlarla aynı ayarda 40 pârelik basılmasına karar verilmişti ${ }^{18}$. Arşiv evrakından net bir şekilde tespit edilebilen bu husus, numismatik kaynaklarda doğru değerlendirilememiştir. İsmail Galip, Hasan Ferid, Nuri Pere ve Cüneyt Ölçer tam ve yarım cihâdiye ile birlikte 50 pârelik basıldığını ileri sürerler. Arşiv belgesine istinat etmedikleri için meseleyi tam olarak anlayamadıkları açıktır. Ancak arşiv belgesine bakmadığı halde Benjamin Bass dikkati sayesinde bunun 50 değil 40 pârelik olduğunu,

\footnotetext{
17 HH.d, nr. 15352, vr. 2a; Tablo II; C.DRB, nr. 40/1964; 36/1632; 40/2055; 5/211; İsmail Galib, Takvim-i Meskûkât-ı Osmâniyye, İstanbul 1307, s. 378, 412-413; Hasan Ferid, Nukud ve itibari Mâli, Hukuk Matbaası, İstanbul 1330, c. I, s. 191-192; 197; İbrahim Artuk, "Cihâdiyye" Türkiye Diyanet Vakfı İslam Ansiklopedisi, İstanbul 1993, VII, 534; Mehmet Zeki Pakalın, Osmanlı Tarih Deyimleri ve Terimleri Sözlüğü, İstanbul 1983, c. I, s. 291.

${ }^{18}$ C.DRB, nr. 40/1964; 36/1632; 40/2055; 5/211.
}

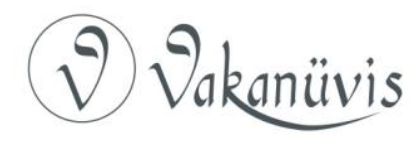


diğer numismatların yanıldığını tespit edebilmiştir. Cüneyt Ölçer'de ilk çalışmasında aynı hataya düşmesine rağmen, konuyla ilgili ikinci eserinde verdiği bilgileri tashih etmiş ve söz konusu sikkenin 50 değil 40 pârelik olduğunu ifade etmiştir ${ }^{19}$.

Tartışmalı bir diğer husus ise cihâdiyenin ilk defa hangi tarihte basılmaya başlandığıdır. Dönemin vekayinüvisi Şanizâde daha evvelden alınan cihâdiye basma kararının ilk defa Hicrî 1 Zilhicce 1227 (Miladî 6 Aralık 1812) tarihinde uygulamaya konulduğunu yazar. Ancak İsmail Galib Bey, incelediği cihâdiyeler üzerindeki bazı ipuçlarına dayanarak buna itiraz etmektedir. İlk cihâdiyelerin Şanizâde'nin verdiği tarihten iki yı önce darp edilmeye başlandığını, vekayinüvisin bahsettiği sikkelerin ikinci tertip cihâdiyeler olduğunu ifade eder. Arşiv belgeleri de İsmail Galip Beyi doğrulamakta, ilk cihâdiyelerin Hicrî 1225 (Miladî 18101811) yılında basılmaya başlandığına dair kanıtlar sunmaktadır ${ }^{20}$.

Maden ocaklarından darphaneye gelen 54 ton gümüşten basılan diğer iki sikke türü ise önce 3 dirhemlik ve 2 dirhemlik kuruşlardı. Bunların ayarı \% 51'di. Vezni üç dirhem olan kuruşlardan 6.266.925,5 adet basılmış; 3.356.269,5 kuruş gelir sağlanmıştı. Elde edilen kâr $\% 54$ 'e yakındı. Kullanılan gümüşün bir dirheminin maliyeti ortalama 33 akçeydi. İki dirhem vezninde basılan kuruş ve kesirlerinin miktarı 1.475.124,5; elde edilen faiz ise 823.311 kuruştu. Kullanılan gümüşün bir dirheminin maliyeti ise ortalama 47 akçeydi $^{21}$. Üç dirhem veznindeki kuruşlar II. Mahmud'un saltanatının üçüncü yılı başında, cihâdiye ile birlikte basılmaya başlanmıştır ${ }^{22}$. íki dirhemlik kuruşlar ise Hicrî 1236 (Miladî 1820-1821) yılından itibaren darp edilmiştir. Gümüşün piyasa fiyatındaki artış nedeniyle para kurlarında ciddi bir

\footnotetext{
${ }^{19}$ İsmail Galib, Takvim, s. 378, 379; Hasan Ferid, Nukud, c. I, s. 191-192; Nuri Pere, Osmanlılarda Madeni Paralar, İstanbul 1968, s. 249; Benjamin Sass, "The Silver and Billon Coins Minted at Constantinople Under Sultan Mahmud II (1223-1255 H.) "The American Numismatic Society Notes, 18 (1972), s 169, 171; Cüneyt Ölçer, Sultan Mahmud II Zamanında Darp Edilen Osmanlı Madeni Paraları, İstanbul 1970, s. 16, 45, 46; Sultan Mahmud II Zamanında Darp Edilen Osmanlı Madeni Paraları, yayına hazırlayan: C. Ender, İstanbul, s. 12-14 (bu eser ilkini ikmal etmek için yayınlanmıştır).

${ }^{20}$ C.DRB, nr. 40/1964; 36/1632; 40/2055; 5/211; Şani-zâde Mehmed 'Ata'ullah Efendi, Şâni-zâde Târîhi [Osmanlı Târihi (1223-1237/1808-1821)], haz. Ziya Yılmazer, İstanbul 2008, c. I, s. 595-596; İsmail Galib, Takvim, s. 412-413

${ }^{21}$ HH.d, nr. 15352, vr. 2a; Tablo II.

${ }^{22}$ Hasan Ferid, Nukud, s. 191-192; İsmail Galib, Takvim, s. 379, 413.
}

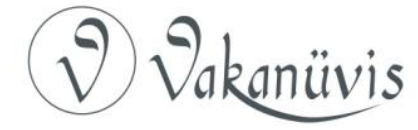


yükselme olmuş, çarşı pazarda spekülasyonlar artmış, bu yüzden kuruşun vezninde değişiklik yapılması zorunlu hale gelmiştir ${ }^{23}$.

Hicrî 1223-1239 (Miladî 1808-1824) yılları arasında maden ocaklarından darphaneye gelen 54 ton civarındaki gümüşten basılan diğer sikke türü ise zolota ve bunun ikilikleriydi. İkilikler altmışlık olarak da adlandırılıyordu. Lehistan kökenli bir para olan zolota, Osmanlı piyasasında XVII. yüzyıldan itibaren sıklıkla görülmeye başlanmış, daha sonra Darbhâne-i Âmire'de yerli zolotalar basılmıştır. Zolotanın kıymeti kuruşun dörtte üçü, yani 30 pâreydi. II. Mahmud'un saltanatının ilk yıllarında da zolota basılmış, Hicrî 1239'da (Miladî 1823-1824) ise yeni tipte zolota ve çifte zolota darbına başlanmıştır. Ayarı \%61 olan zolotaların vezni 1 dirhem, basılan toplam zolotanın kuruş cinsinden değeri 1.096.286'ydı. Elde edilen gelir 519.931 kuruş, para basımında kullanılan gümüşün bir dirheminin ortalama maliyeti ise 71 akçeydi $^{24}$.

Darphanenin 1788-1824 yılları arasında para basımında kullandığı 159 ton gümüşün \%66'sı 4 dirhemlik kuruş, \%21'i 3 dirhemlik kuruş, \%8'i cihâdiye, \%3'ü 2 dirhemlik kuruş, \%2'si zolota basımında kullanıımıştı ${ }^{25}$. Darphane gümüş parayı tağşiş ederek, sıkıntı içindeki devlet hazinesine destek olmuş, askerî giderlerin finanse edilmesini sağlamıştır.

\section{Darphanenin Piyasadan Satın Aldığı Altından Sikke Basarak Elde Ettiği Gelir (1788-1825)}

Osmanlı maliyesinde darphanede basılan paradan elde edilen gelire darp faizi denilirdi. Sikke basmak padişaha mahsus bir hak olduğu için darp faizinin saraydaki Enderun Hazinesi'ne teslim edilmesi gerekirdi. Bu paradan başta padişah olmak üzere hanedan mensubu çeşitli kimselere aylık ödemeler yapılıyordu. XVIII. yüzyılın ikinci yarısında darphane ihtiyat hazinesine dönüşünce darp gelirinden askeri giderler

\footnotetext{
${ }^{23}$ Şani-zâde Mehmed 'Ata'ullah Efendi, Şâni-zâde Târîhi, c. II, s. 1144-1145.

${ }^{24}$ HH.d, nr. 15352, vr. 2a; Tablo II; Hasan Ferid, Nukud, s. 194-195, 197; İsmail Galib, Takvim, s. 377-378, 414; Bazı tespitleri eksik ve hatalı olmasına rağmen zolota için bakınız: Ibrahim Artuk, "Zolota" Türkiye Diyanet Vakfı Islam Ansiklopedisi, İstanbul 2013, XLIV, 500-501.

${ }^{25}$ HH.d, nr. 15352, vr. 1b, 2a; Tablo II.
}

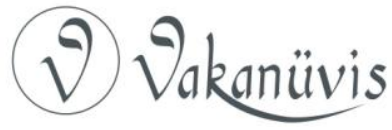


için de ödemeler yapılmaya başlandı ${ }^{26}$. Aynı dönemde darphanede altın para darbı gümüş sikke basımının gerisindeydi. Dolayısıyla altın sikkeden elde edilen darp geliri sınırlı miktardaydı. Ancak daha sonra altın sikke darbı ve darp faizi artmıştır ${ }^{27}$.

İcmâl defterinin ihtiva ettiği Muharrem 1203-Receb 1240 (Miladî 1788-1825) arasındaki dönemde fındık, zer-i mahbûb, İstanbul, rûmî ve adlî altınları darp edilmiştir ${ }^{28}$. Grafik II ve Tablo III incelendiğinde görüleceği üzere otuz yedi buçuk yıllık süreçte altın sikke darp gelirinde artış ve azalışlar yaşanmıştır. Darp faizi Hicrî 1209'dan (Miladî 17941795) sonra artış trendine girmiş, Hicrî 1214 (Miladî 1799-1800) yılında düşmeye başladıktan sonra, Hicrî 1220'lerde (Miladî 1805-1806) tekrar yükselişe geçmiş, Hicrî 1225'e (Miladî 1810-1811) kadar arttıktan sonra yine azalmaya başlamıştır. Hicrî 1231'de (Miladî 1815-1816) yeni bir artış trendi yakalamış ve Hicrî 1238'de (Miladî 1822-1823) zirveye ulaşmıştır.

Darp gelirinin miktarı darphanenin mübâyaat imkanlarıyla doğrudan ilişkiliydi. Darphanenin mübâyaat kapasitesi ise piyasa şartları, devletin malî politikaları ve kurumun iç dinamiklerinin etkisi altında şekilleniyordu. Bu dönemde devlet hazinesinin karşılaması gereken çok büyük masraflar vardı. Bir biri ardına patlak veren iç ve dış sorunlar devleti malî açıdan ağır bir sıkıntıya sokmaktaydı. Mesela darp faizinin zirveye çıktığı dönemde Rum isyanı yaşanmakta, hazine isyanın bastırılması için girişilen askerî harekat yüzünden büyük miktarda paraya ihtiyaç duymaktaydı. Darphane, devlet hazinesinin en büyük destekçisi ve masrafların karşılanması hususunda en önemli rolü üstlenen devlet kurumuydu. XVIII. yüzyılın ikinci yarısında ihtiyat

\footnotetext{
${ }^{26}$ TSMA.D, nr. 2379/1-12; 2380/1-12; D.BŞM.d, nr. 41039; Bölükbaşı, Darbhâne-i Âmire, s. 120-125.

${ }^{27}$ Bölükbaşı, Darbhâne-i Âmire, s. 115.

${ }^{28}$ Bu altınlar için bakınız: Râşid Mehmed Efendi, Çelebizâde İsmaîl Âsım Efendi, Târîh-i Râş̧id ve Zeyli, hazırlayanlar: A. Özcan, Y. Uğur, B. Çakır, A. Z. İzgöer, İstanbul 2013, II, s. 981; İsmail Galib, Takvim, s. 253, 272-276, 281; Sahillioğlu, Bir Asırlık, s. 109-117; Brian D. Johnson, The Ottoman Currency System (1687-1754), Unpublished Ph.D Thesis, University of Washington, 1999, s. 170-175; İbrahim Artuk, "Fındık Altını" Türkiye Diyanet Vakfı İslam Ansiklopedisi, İstanbul 1996, XIII, 27-28; "Zer-i Mahbûb" Türkiye Diyanet Vakfı İslam Ansiklopedisi, İstanbul 2013, LXIV, 281-282; "Adlî Altın" Türkiye Diyanet Vakfı Islam Ansiklopedisi, İstanbul 1988, I, 389; Pakalın, Tarih Deyimleri, III, s. 58.
}

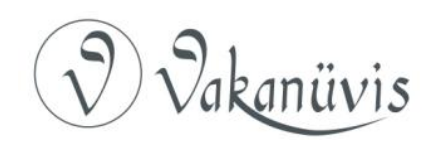


hazinesine dönüşmesiyle bu mühim rolü üstlenmiş, III. Selim döneminde İâd-ı Cedid Hazinesi'nin kurulmasıyla önemi nispeten azalmışsa da, II. Mahmud devrinde tekrar ön plana çıkmıştı. Gerek para sisteminde yapılan bir takım ayarlamalar ve düzenlemelerle, gerekse kendisine bağlanmış olan başka gelir kaynaklarını kullanarak hazineye destek oluyordu ${ }^{29}$.

Darphanenin para basım gelirinde ortaya çıkan artışların yaşanan malî krizlerle yakın ilişkisi vardır. Darp faizinde yaşanan ilk yükseliş Hicrî 1209-1214 (Miladî 1794-1800) yılları arasına tekâbül etmektedir. Yukarıda da temas edildiği üzere bu dönemde herhangi bir tağşiş olmadığı için bunun reel bir artış olduğu söylenebilir. Hicrî 1220'lerde (Miladî 1805-1806) başlayan yeni bir yükseliş trendi ise $1225^{\prime}$ lerde (Miladî 1810-1811) zirveye ulaştıktan sonra tekrar düşüşle sonuçlanmıştır. II. Mahmud dönemi tağşişlerinin cihâdiye ve 3 dirhemlik kuruşların Hicrî 1225 'te darbıyla başladığı yukarıda belirtilmişti. O zaman Hicrî 1220-1225 yılları arasındaki yükseliş reel bir artış olarak kabul edilebilir. Hicrî 1225 'ten sonraki düşüş ise tağşişler göz önünde bulundurulduğunda tablo ve grafiklerde gösterildiğinden çok daha büyüktür. Bu noktada gözden kaçırılmaması gereken husus, Sultan II. Mahmud'un henüz eski altın sikkeleri darp ettirmeye devam etmesi, yeni bir altın sikke basımına girişmemiş olmasıdır ${ }^{30}$.

Darphane Hicrî 1231 yılı Cemaziyelahir (Nisan-Mayıs 1816) ayından itibaren yeni bir altın sikke olan rûmî altınını basmaya başlamıştır. Bu yeni altın sikkenin basımında ki temel sebebin altın darp gelirinde başlayan düşüşü durdurmak ve yeni bir artış trendi yakalamak olduğu

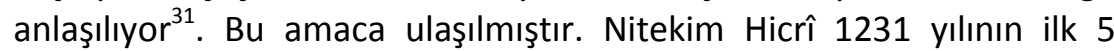
ayında darp faaliyetinden sadece 117.482 kuruş gelir elde edilmişken, rûmî basılmaya başlandıktan sonra kalan 7 ayda 1.690.060,5 kuruş gelir elde edilmiştir ${ }^{32}$. Darp geliri Hicrî 1236 yılı Şaban (Mayıs-Haziran

\footnotetext{
${ }^{29}$ HAT, 567/27820. Darphanenin ihtiyat hazinesi olması hususunda bakınız: Bölükbaşı, Darbhâne-i Âmire, s. 133-200; Bu dönemde yaşanan iç ve dış problemler ile maliye sistemi hakkında şu eserlere bakılabilir: Ali Akyıldız, Tanzimat Dönemi Osmanlı Merkez Teşkilâtında Reform, İstanbul 1993, s. 92-127; Yüksel Çelik, Şeyhü'l-Vüzerâ Koca Hüsrev Paşa, II. Mahmud Devrinin Perde Arkası, İstanbul 2013, s. 183-249.

${ }^{30}$ HH.d, nr. 15352, vr. 2b-3; Tablo III.

${ }^{31}$ HAT, 280/16545; 285/17113; 1275/49507.

${ }^{32}$ HH.d, nr. 15352, vr. 3a; Tablo III.
}

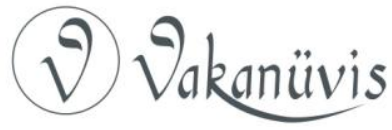


1821) ayından sonra tekrar artmaya başlamıştır. Bu artışın sebebi ise rûmî altınının yeni bir türünün basılmaya başlanmasıdır. Nitekim Hicrî 1236 yılının ilk 7 ayında toplam 2.436. 881 kuruş gelir elde edilmişken, kalan beş ayda daha fazla darp faizi elde edilerek 2.682.611 kuruş rakamına ulaşılmıştı ${ }^{33}$. illk rûmîler 1,5 dirhem vezninde, 23 ayarında (binde 956,3) basılırken; yenileri ise aynı vezinle 19 kırat 1 buğday ayarında (binde 802) basılıyordu. Yeni rûmîlerin altın içeriği eskilerin $\% 83$ 'ü civarındaydı ${ }^{34}$. Sultan II. Mahmud döneminde gümüş paraların tağşişiyle devlet hazinesinin giderlerinin finanse edildiği bilinen bir husustur. Yukarıda yer alan rûmî altını basımıyla ilgili örneklerden anlaşıldığı üzere altın sikkelerin vezin ve ayarının düşürülmesiyle de finansman sağlanmıştır. Elde edilen meblağ gümüş sikke tağşişinden sağlanan paraya göre daha düşük olsa da kayda değer miktardadır ${ }^{35}$.

Altın sikke tağşişinin devlet hazinesi lehine nasıl bir gelir sağladığı hususunu daha net gösterecek bir örnek verelim. Eklerde yer alan Tablo IV'te görüldüğü üzere Hicrî 1222 yılının Receb ayında (Eylül-Ekim 1807) 172.511 dirhem halis altından zer-i mahbûb kesilmiş ve 131.667 kuruş gelir temin edilmiştir. Hicrî 1237 yılı Cemaziyelevvel ayında (Ocak-Şubat 1822) ise 162.421 dirhem halis altından rûmî ve İstanbul altını kesilmiş 667.574 kuruş gelir elde edilmiştir. Darp gelirindeki artış beş kattan fazladır. Ancak bu rakamlar kuruş üzerinden verildiği için reel karşılığının bulunması gereklidir. O nedenle elde edilen gelir gram gümüş cinsinden tespit edilmelidir. Elimizdeki ilk rakam 861.365 gram gümüşe, ikinci ise 1.548 .771 gram gümüşe tekâbül etmektedir. Dolayısıyla defterde gösterildiği gibi beş kat değilse bile, darphanenin

33 HAT, 280/16545; HH.d, nr. 15352, vr. 3; Tablo III; İsmail Galip, Takvim, s. 370; Süleyman Sûdî, Usûl-i Meskûkât-ı Osmaniyye ve Ecnebiyye, (yay. ỉbrahim Artuk, Cevriye Artuk), İstanbul 1982, s. 72-75; Ölçer, Sultan Mahmud II, 1970, s. 14, 23-25.

${ }^{34}$ Bilindiği üzere Osmanlılar altının ayarını 24 kırat üzerinden ifade ediyorlardı. Ancak daha sonra Avrupa darphanelerinden ilhamla milyem hesabı da kullanılmaya başlanmış, yani bin üzerinden de söylenmiştir. Illk basılan rûmîlerin ağırlığı 4,810 gramken, saf altın içeriği 4,610 gramdı. Yeni rûmîlerin saf altın içerikleri ise 3,858 gramdı (D.DRB.MH, 236/76; 239/28).

${ }^{35}$ HAT, 567/27820; Pamuk, En Büyük Tağşiş, s. 123-131

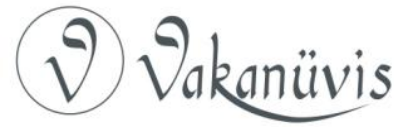


elindeki çeşitli enstrümanlar kullanılarak iki kat civarında reel bir gelir artışı sağlanmıştır ${ }^{36}$.

Darp faizinin zirveye çıkması ise Hicrî 1237 yılı Zilhicce (AğustosEylül 1822) ayından sonradır. Bu dönemde hazine acilen nakit paraya ihtiyaç duyuyordu. Rum isyanı sırasında masrafların iyice artması, Sultan II. Mahmud'u ve devlet ricalini büyük sıkıntıya sokmuştu. Padişah devlet adamlarından meselenin bir an önce çözülmesini, masrafların finansmanı için para bulunmasını istiyordu. Bu amaçla verdiği talimatlardan para ayarlamalarından büyük beklenti içinde olduğu anlaşılıyor. Soruna çözüm bulunması için kimi zaman dar kapsamlı hususî toplantılar, bazen de geniş katılımlı şûralar tertip ediliyordu. Padişahın bu toplantılarda mutlaka bulunmasını istediği kişi ise Darphane Mübâyaacısı Kazaz Artindi ${ }^{37}$. Yapılan toplantıların neticesi padişaha raporlar halinde arz ediliyordu. Sunulan raporlarda altın sikkelerin ayarının çeşitli oranlarda düşürülmesi durumunda ne kadar gelir elde edileceği veya başka ne gibi düzenlemeler yapılabileceği açıklanarak alternatifler üzerinde duruluyordu. Girişilecek uygulamaların yol açabileceği toplumsal tepkilerden çekindikleri için olsa gerek, başta Şeyhülislam Efendi olmak üzere sürece ulemanın da müdâhil olmasını sağlıyorlardı. Uzun müzakerelerin ardından yeni bir sikke basılması, bu sikkenin yüksek ayarlı, fakat düşük vezinli olması kararı alındı. Ayrıca kıymetli maden kullanımına sınırlandırma getirilerek belirli bir fiyat üzerinden altın ve gümüş toplanacaktı. Bu

\footnotetext{
${ }^{36}$ D.DRB.d, nr. 925; D.DRB.MH, 250/23 ve 250/27; HH.d, nr. 15352, vr. 2b-3; Tablo III ve IV; Pamuk, En Büyük Tağşiş, s. 131; Bölükbaşı, Darbhâne-i Âmire, 132.

37 Sultan II. Mahmud'un altın ve gümüş kullanımını sınırlandırdığı dönemde darphanede de önemli bazı gelişmeler yaşanmıştı. Piyasadan kıymetli maden temin etme işinden sorumlu olan darphane ifrazcıbaşısı (mübâyaacı) değişmişti. Bu görevi 1762 yılından beri meşhur Ermeni Düzoğlu ailesi yerine getiriyordu. Görevlerinde gösterdikleri başarı nedeniyle olsa gerek birkaç kuşak bu vazifeyi sürdürdüler. Ancak 1819 yılında (Hicrî 1235) dönemin darphane nâzırı Abdurrahman Feyzi Beyle birlikte Ifrazcıbaşı Düzoğlu Kirkor ve kardeşi Sarkis idam edildiler. Yolsuzluk yapmak ve görevlerini kötüye kullanmakla suçlanmışlardı. Enteresan bir şekilde idam edildikleri tarih altın mübâyaatından sağlanan kârın ciddi bir yükselişe geçtiği yıllara denk gelir. Ölümlerinden iki yıl sonra ise altın darbından elde edilen gelir zirveye çıkmıştır. Zirvenin görüldüğü yıl ise mübâyaat işinin başında II. Mahmud dönemi para tarihinde derin izler bırakan Kazaz Artin vardı (Bölükbaşı, Darbhâne-i Âmire, s. 52-57).
}

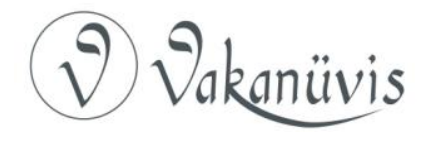


sayede düşük fiyata toplanacak altından sikke basımıyla yüksek oranda gelir sağlanması amaçlanıyordu ${ }^{38}$.

Adî̂ ismiyle yeni bir altın sikke basılmaya başlanmışs, kıymetli madenin kullanımı sınırlandırılarak darphanenin daha uygun şartlarda mübâyaat yapabilmesi temin edilmiştir. Öncelikle şeyhülislama başvurulmuş, askerî masraflar bu kadar yüksekken ve düşman tehlikesi varken bazı istisnaî durumlar hariç altın ve gümüş eşya kullanmanın haram olduğu, bunların Darbhâne-i Âmire'ye teslim edilmesini âmir bir ferman çıkarsa buna uymanın farz olduğu yönünde fetva alınmıştır. Ardından Hicrî 21 Zilhicce 1237 (Miladî 8 Eylül 1822) tarihinde çıkarılan ferman ile kadın ziyneti başta olmak üzere bazı istisnaî alanlar dışında kıymetli maden kullanımı yasaklanmıştır. Herkesin elindeki altın ve gümüşü darphaneye teslimi emredilmiştir. Taşraya da fermanlar yazılmış, ahalinin altın ve gümüşten yapılma eşyayı bulundukları yerdeki valiye, vali yoksa mütesellim veya voyvodalara belirlenen fiyat üzerinden teslim etmesi talimatı verilmiştir. Darphane altının dirhemi için 16 kuruş, gümüşün dirhemi için ise 32 pâre ödeme yapacaktı. Teslimat için 40 gün süre tanınmış, daha sonra yapılacak teftişlerde altın ve gümüş yakalatanların cezalandırılacağı ilan edilmiştir. Hanedan mensuplarından başlayarak vüzera, ulema, kâtipler, askerler ve esnaf dahil toplumun her sınıfından altın ve gümüş bekleniyordu ${ }^{40}$.

\footnotetext{
${ }^{38}$ HAT, 285/17113; 1275/49507; 564/27652; Ölçer, Sultan Mahmud II, 1970, s. 26-29.

${ }^{39}$ Adlî altını cedid rûmîlerden daha hafif, ancak ayarı bir miktar daha yüksekti. Sekiz kırat (1,6 gram) vezne sahip olan adlîler, 20 ayarındaydı (binde 833). Saf altın içeriği ise 1,33 gramdı (Hasan Ferid, Nukud, s. 209; Pere, Madeni Paralar, s. 244-245).

${ }^{40} 28$ Eylül 1222 (11 Muharrem 1238), C.DRB, 25/1250; 9 Ekim 1822 (22 Muharrem 1238), C.DRB, 19/923; 9 Kasım 1822 (23 Safer 1238), 35/1705; 16 Aralık 1822 (1 Rebiülevvel 1238) 19/920; HAT, 279/16505; Sahhâflar Şeyhi-zâde Seyyid Mehmed Esad Efendi, Vak'a-nüvis Esad Efendi Târihi (Bâhir Efendi'nin Zeyl ve Ilaveleriyle) 12371241/1821-1826, haz. Z. Yılmazer, İstanbul 2000, s. 119-120; Ahmed Cevdet Paşa, Târih-i Cevdet, Dersaadet 1309, c. XII, s. 45; Yapılan bu operasyon 1787-1792 Osmanlı Rus Savaşı'nın en buhranlı döneminde peş peşe ikilik ve yüzlük basıldığında I. Abdülhamid ve III. Selim'in yaptığı uygulamayı hatırlatmaktadır. O zamanda altın ve gümüş kullanımı sınırlandııılmış, cebrî tedbirlerle kıymetli maden toplanmış ve büyük bir emisyon artışı yaşanmıştı. Darphanenin gümüş para emisyonu yıllık 8 milyonu biraz aşarken, altın ve gümüş kullanımının sınırlandırılmasıyla birlikte 25 milyon kuruş civarına yükselmişti. Aynı dönemde yıllık darp geliri de 1 milyon civarından 7,5 milyon kuruş civarına çıkmıştı (Bölükbaşı, Darbhâne-i Âmire, s. 113-132).
}

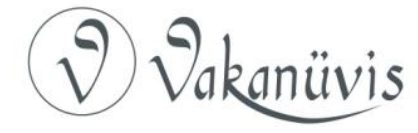


Kıymetli maden kullanımına yasak getirilmesinin ardından alınan ikinci tedbir ise yeni basılmaya başlanmış olan adlî altını dışındaki eski altın sikkelerin tedavülünün yasaklanması ve adlînin kur değerinin arttırılmasıydı. Bu konudaki hazırlıklar gizlice yürütülmüştü. Padişahın yakın çevresindeki kişiler arasında mesele müzakere edilmiş, hazırlıklar kimseye duyurulmadan yapılmıştır. Neticeye ulaşılıp karar kesinleşince kamuoyuna bilgi verilmiştir. Adlî altınının yüksek ayarlı olduğu, bu nedenle 10 kuruşa tedavül etmesinin doğru olmadığı, ilk tedavüle çıktığında değerinin 10 kuruş olarak açıklanmasının darphane memurlarının sehven yaptığı hatadan kaynaklandığı ifade edilmiştir ${ }^{41}$. Alınan karar çerçevesinde eski altın sikkelerin tedavülü yasaklanmış, bunların belirlenen fiyat üzerinden darphaneye satılması mecburî tutulmuştur. Darphaneye altın sikke getirenlere karşılığında tamı 12, yarımı 6, çeyreği 3 kuruş hesabıyla adlî altını verilecekti. Devletin koyduğu fiyatlar yüzünden bu ticaret darphanenin lehine, eski altın getirenlerin aleyhineydi. Ancak devlet malî zaruretler nedeniyle böyle bir uygulamaya gitmek zorunda kalmıştı. Devletin bu tür cebrî uygulamalarının olumsuz sonuçları da olmakla birlikte, darphane mübâyaatında ciddi miktarda artış sağlanmıştı ${ }^{42}$. Bu artıştan padişah çok memnun olmalı ki, darphaneye gelen altın ve gümüşün kaydını tutan kâtipleri ödüllendirmişti ${ }^{43}$.

Dönem başıyla dönem sonu arasında yaşanan darp faizi artışını karşılaştırmak, altın darp gelirindeki artışı somut bir şekilde görmek için faydalı olacaktır. Hicrî 1204 yılında darp faizi 270.884 kuruş iken, 1238 yılında 27.810.354'e çıkmıştır. Nominal artış 102 kat civarındadır. Ancak önemli olan reel olarak ne kadar arttı̆̆ıdır. Reel artışı bulmak için eldeki rakamlar gram gümüşe çevrilmelidir. Illk rakam 1.772.123 gram, ikincisi ise 64.520.021 gram gümüşe tekâbül etmektedir. Reel artış 36 kat civarındadır. Bu oranda bir artış oldukça yüksektir. Devletin aldığı cebrî tedbirlerin zararları orta ve uzun vadede mutlaka ortaya

\footnotetext{
${ }^{41}$ HAT, 567/27822; 564/27699.

4226 Mart 1825 (6 Şaban 1240), C.DRB, 19/924; 4 Nisan 1825 (15 Şaban 1240), 47/2306; 30 Mayıs (12 Şevval 1240), 30/1472; Sahhâflar Şeyhi-zâde Seyyid Mehmed Esad Efendi, Esad Efendi Târihi, s. 128; Ahmed Cevdet Paşa, Târih, s. 53-54.

${ }^{43}$ HAT, 567/27812.
}

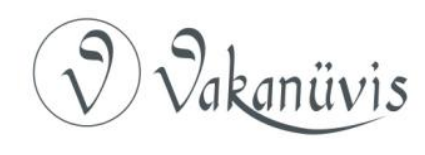


çıkacaktı. Ancak kısa vadede devlet hazinesi acil nakit ihtiyacını söz konusu tedbirler sayesinde karşılayabilmiştir ${ }^{44}$.

İcmâl defterinin yalnızca darp faizi hakkında bilgi vermesi, basılan toplam altın sikke miktarını ihtiva etmemesi büyük bir eksikliktir. Acaba darp faizinden yola çıkarak basılan toplam altın miktarı bulunabilir mi? Bu ulaşılması zor bir hedeftir. Daha doğrusu bu konuda birtakım hesaplamalar ve çıkarımlar yapılabilir. Ancak ulaşılan sonuçlar yeterince sağlıklı olmayacaktır. Birbirinden farklı sikkelerin darp edildiği, değişken şartlarda mübâyaat yapıldığı bir süreçte ortalamayı temsil eden sağlıklı bir kâr oranı tespit etmek çok zordur. Üstelik defterde darp geliri kuruş olarak verilmektedir. Bu dönemde kuruş önemli oranda tağşişe uğradığı için rakamlar reel kâr oranını göstermemektedir. Ancak bu konuda fikir vermesi için icmâl defterinin başka arşiv belgeleriyle desteklenmesiyle Tablo IV oluşturulmuştur. Söz konusu tabloda Hicrî 1222 (Miladî 1807-1808) yılına ait dokuz ayda ve 1237 yılı Cemaziyelevvel (Ocak-Şubat 1822) ayında mübâyaat altınından darp edilen toplam altın sikke miktarı gösterilmektedir. Bu verilere göre darphane 1222 yılında ortalama \%7,5 oranında kâr elde etmiştir. Hicrî 1237 yılı Cemaziyelevvel ayında kâr oranı \%20'yi aşmıştır. Yukarıda da açıklanmaya çalışıldığı üzere darphane standartları farklı yeni altın sikkeler basmaya başladıktan sonra kâr

\footnotetext{
${ }^{44}$ Örnek olarak Hicrî 1204 ve 1238 yılları özellikle seçilmiştir. Çünkü bu yıllarda kuruş tağşiş edilmemiştir. Yıl içinde bir tağşiş olması hesap işlemlerini zorlaştıracak; eğer tağşişin gün, ay, yıl olarak tam tarihi bilinmiyorsa imkansızlaştıracaktır. Kuruş gram cinsinden gümüşe çevrilirken 1204 yılı için Bölükbaşı'nın; 1238 yılı içinse Pamuk'un verileri esas alınmıştır (HH.d, nr. 15352, vr. 2b-3; Tablo III; Pamuk, En Büyük Tağşiş, s. 131; Bölükbaşı, Darbhâne-i Âmire, s. 132). Okuyucuların aklına Tablo III'te yer alan ve darp faizini gösteren rakamların neden tamamının gram cinsinden gümüşe çevrilmediği sorusu gelebilir. Eğer bu yapılsaydı tabloda yer alan ve nominal artışı gösteren rakamlar reel artışı gösterir hale gelebilecekti. Bunun yapılmamasının başlıca gerekçesi, gümüş üzerinde yapılan tağşişlerin tarihini sadece yıl olarak bilebilmemizdir. Maalesef henüz literatürde II. Mahmud dönemi tağşişlerinin tarihlerini gün, ay ve yıl olarak gösteren bir veri yoktur. Bu noktada Tablo III'te yer alan yıllık rakamların aylık dökümlerinin icmâl defterinde yer aldığını belirtelim. Eğer elimizde kuruş üzerindeki tağşişlerin tarihini gün, ay ve yıl olarak gösteren bir veri olsaydı çevirme işlemi kolaylıkla yapılabilirdi. Bu olmadığı için Tablo III'teki rakamların tamamının gram cinsinden gümüşe çevrilmesi tercih edilmemiş, sadece örnek bazı yıllardaki rakamlar çevrilmiştir.
}

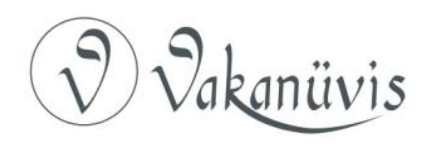


oranı yükselişe geçmiştir. Sürecin tamamı için açıklayıcı olmasa da, Tablo IV'te yer alan kâr oranları belli ölçüde fikir vermektedir ${ }^{45}$.

Son olarak icmâl defterinin güvenilirliği konusunda birkaç söz edilmelidir. Farklı kaynaklardan oluşturulan Tablo IV bu konuda da aydınlatıcıdır. Kâtiplerin hesaplama ve kayıt işlemleri sırasında kimi zaman hata yaptığı bilinen bir gerçektir. Özellikle mufassal defterlerden icmâller hazırlanırken ciddi hatalar ortaya çıkabilmektedir. Tablo IV'ün son dört sütununda yer alan veriler icmâl defteriyle mufassalların karşılaştırı ması imkânını sağlamaktadır. Buna göre elimizdeki on aylık karşılaştırmalı verinin, beş ayında hiç hata yoktur. Iki ayda ise binde biri bile bulmayan çok küçük hatalar yapılmıştır. Kalan üç aydan Hicrî 1222 yılı Zilhicce ayında mufassal defterdeki rakamlar icmâl deftere geçirilirken \%8,63; Receb ayında $\% 14,38$ oranında hata yapılmıştır. Rebiülahir ayında ise çok fahiş bir hata ile \%49'luk bir yanlışlık ortaya çıkmıştır. Elimizdeki 10 ay için hata ortalaması \%7 civarındadır. Rebiülahir ayı hesaba katılmazsa hata oranı $\% 2,5^{\prime}$ lara inmektedir ${ }^{46}$. Bu hata oranı defterdeki verilerin güvenilirliğini kısmen zedelese de, dönemin para tarihi hakkında çok önemli bilgiler sağladığı gerçeğini değiş̧irmemektedir.

\section{Genel Değerlendirme ve Sonuç}

Küçük Kaynarca Antlaşması'nın 1774 yılında imzalanmasıyla birlikte Osmanlı Devleti tarihinin en büyük siyasî buhranına girmiştir. Bu süreçte yaşanan iç ve dış problemlerin ekonomik ve malî bedeli çok ağır olmuş, devlet hazinesi ortaya çıkan masrafların finansmanında yetersiz kalmıştır. Yaşanan malî sorunların aşılmasında tağşişlerin önemli katkısı olmuştur. Uzun vadede sosyal ve ekonomik açıdan büyük zararlara yol açsa da, Osmanlı idarecileri mevcut zaruretlerin etkisiyle tağşişlere sıklıkla başvurmuşlardır.

Literatürde gümüş sikkelerin tağşişiyle büyük gelir sağlandığı, malî krizin aşılmasında tağşiş gelirinin önemli katkısının olduğu vurgulanmaktadır. Bu makaleye konu olan icmâl defteri ise krizin

\footnotetext{
${ }^{45}$ HH.d, nr. 15352, vr. 2b-3; Tablo III ve IV.

${ }^{46}$ D.DRB.d, nr. 925; D.DRB.MH, nr. 250/23; 250/27.; HH.d, nr. 15352, vr. 2b-3.
}

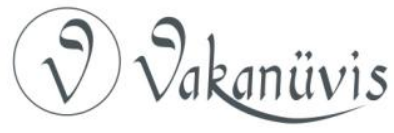


aşılmasına altın sikke basımının katkısını gözler önüne sermektedir. Bu katkı gümüş kuruşun tağşişiyle sağlanan gelirin gerisinde kalsa da, kayda değer miktardadır. Devlet altın sikkelerin vezin ve ayarını düşürme, altından mâmul eşyanın kullanımını sınırlandırma, eski altın paraların tedavülünü yasaklama, yeni basılan altın sikkelerin piyasa değerini arttırma gibi birtakım yöntemler kullanarak altın sikke basımından büyük gelir sağlamıştır.

Altın sikke darbının verimli bir finansman aracına dönüştüğünü ortaya koyan icmâl defteri aynı dönemde, darphanenin maden ocaklarından sağladığı gümüş miktarının azaldığını da göstermektedir. Literatürde Osmanlı madenlerinin üretim rakamlarını düzenli seriler halinde gösteren çalışmalar çok azdır. İcmâl defterinin ihtiva ettiği 1788-1824 dönemi söz konusu olduğunda ise durum daha da kötüdür. Literatürdeki noksanlık düşünüldüğünde otuz altı yıllık düzenli bir veriye sahip olmak büyük kıymet kazanmaktadır. Bu istatistiki veri sayesinde Osmanlı madenlerinde yapılan üretimin büyük bir düşüş yaşadığı da tespit edilebilmektedir. Söz konusu dönemin başında sekiz buçuk ton civarında olan üretim, dönem sonunda neredeyse dörtte birine düşmüştür. Daha da vahimi yıllık üretim ortalamasının yaklaşık bir asır öncesinin onda biri oranına düşmüş olmasıydı.

Bulgular genel olarak değerlendirildiğinde, 1788-1825 yılları arasında piyasadan satın alınan altından sikke basımının çok önemli bir finansman aracına dönüştüğünü, yine aynı dönemde maden ocaklarında çıkarılan gümüş miktarının büyük bir düşüş yaşadığını tespit edebiliyoruz. Bu konudaki değerlendirmeler eklerde yer alan tablo ve grafiklerin incelenmesiyle daha da müşahhas hale gelecektir. 


\section{Kaynakça}

\section{A-) Arşiv Belgeleri}

\section{Başbakanlık Osmanlı Arşivi (BOA)}

Bâb-ı Defterî Başmuhasebe Kalemi Defterleri (D.BŞM.d): nr. 41039.

Bâb-ı Defterî Başmuhasebe Darbhâne-i Âmire Defterleri (D.BŞM.DRB.d): nr. 16641.

Darbhâne-i Âmire Defterleri (D.DRB.d): nr. 925; 1151.

Mabeyn, Darbhâne ve Hazine-i Hassa Nezareti Defterleri $(H H . d)$ : nr. 15352, 16784; 19612; 19613.

Hatt-ı Hümâyûn (HAT), 279/16505; 280/16545; 285/17113; 564/27652; 564/27699; 567/27812; 567/27820; 567/27822; 1275/49507.

Darbhane-i Âmire Evrakı - Muhasebe (D.DRB.MH), 250/23; 250/27.

Cevdet - Darphane (C.DRB), nr. 5/211; 19/920; 19/923; 19/924; 25/1250; 30/1472; 35/1705; 36/1632; 40/1964; 40/2055; 47/2306.

\section{Topkapı Sarayı Müzesi Arşivi (TSMA) \\ D. (Defterler), nr. 2379/1-12; 2380/1-12.}

\section{Literatür}

Ahmed Cevdet Paşa, Târih-i Cevdet, Dersaadet 1309, c. 12.

Akyıldız, Ali, Tanzimat Dönemi Osmanlı Merkez Teşkilâtında Reform, İstanbul 1993.

Artuk, İbrahim, "Adlî Altın" Diyanet Vakfı İslam Ansiklopedisi, İstanbul 1988, 1, 389.

., "Cihâdiyye" Türkiye Diyanet Vakfı islam Ansiklopedisi, İstanbul 1993, 7, 534.

"Fındık Altını" Türkiye Diyanet Vakfı islam Ansiklopedisi, İstanbul 1996, 8, 27-28.

İstanbul 2013, 64, 281-282.

"Zer-i Mahbûb" Türkiye Diyanet Vakfı Islam Ansiklopedisi, "Zolota" Türkiye Diyanet Vakfı İslam Ansiklopedisi, İstanbul 2013, 44, 500-501.

Behar, Cem, Osmanlı Imparatorluğu'nun ve Türkiye'nin Nüfusu 1500-1927, Tarihi İstatistikler Dizisi II, Ankara 1996.

Bölükbaşı, Ömerül Faruk, XVIII. Yüzyılın Ikinci Yarısında Darbhâne-i Âmire, İstanbul 2013.

,"Osmanlı Taşra Darphaneleri (1697-1758)"

Türk Kültürü Incelemeleri Dergisi, 29, İstanbul 2013, 27-76.

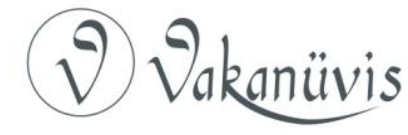


Çelik, Yüksel, Şeyhü'I-Vüzerâ Koca Hüsrev Paşa, II. Mahmud Devrinin Perde Arkası, İstanbul 2013.

Genç, Mehmet, Erol Özvar, Osmanlı Maliyesi: Kurumlar ve Bütçeler, İstanbul 2006, c. 2.

Güran, Tevfik, Osmanlı Tarım Istatistikleri 1909, 1913 ve 1914, Tarihi Istatistikler Dizisi III, Ankara 1997.

Hasan Ferid, Nukud ve İtibari Mâli, Hukuk Matbaası, İstanbul 1330, c. 1.

İsmail Galib, Takvim-i Meskûkât-ı Osmâniyye, İstanbul 1307.

Johnson, Brian D., The Ottoman Currency System (1687-1754), Unpublished Ph.D Thesis, University of Washington, 1999.

Ölçer, Cüneyt, Sultan Mahmud II Zamanında Darp Edilen Osmanlı Madeni Paraları, İstanbul 1970.

Sultan Mahmud II Zamanında Darp Edilen Osmanlı Madeni

Paraları, yayına hazırlayan: C. Ender, İstanbul, (bu eser ilkini ikmal etmek için yayınlanmıştır).

Pakalın, Mehmet Zeki, Osmanlı Tarih Deyimleri ve Terimleri Sözlüğü, İstanbul 1983, c. 3.

Pamuk, Şevket, XIX. Yüzyılda Osmanlı Dış Ticareti, Tarihi İstatistikler Dizisi I, Ankara 1995.

Osmanlı Imparatorluğu'nda Paranın Tarihi, Tarih Vakfı Yurt Yayınları, İstanbul 1999.

“Osmanlı İmparatorluğu'nda Para, 1326-1914" Osmanlı Imparatorlu-ğu'nun Ekonomik ve Sosyal Tarihi, 1600-1914, ed. Halil İnalcık, Donald Quataert, çeviren: Serdar Alper, İstanbul 2004, 2, 1053-1093.

"En Büyük Tağşiş, 1808-1844" Osmanlı Ekonomisi ve

Kurumları, Seçme Eserler I, İstanbul 2007, 123-131.

Pere, Nuri, Osmanlılarda Madeni Paralar, İstanbul 1968.

Râşid Mehmed Efendi, Çelebizâde İsmaîl Âsım Efendi, Târîh-i Râşid ve Zeyli, hazırlayanlar: A. Özcan, Y. Uğur, B. Çakır, A. Z. İzgöer, İstanbul 2013, c. 3.

Sahhâflar Şeyhi-zâde Seyyid Mehmed Esad Efendi, Vak'a-nivüs Esad Efendi Târihi (Bâhir Efendi'nin Zeyl ve Ilaveleriyle) 1237-1241/1821-1826, haz. Z. Yılmazer, İstanbul 2000, c. 2.

Sahillioğlu, Halil, Bir Asırlık Osmanlı Para Tarihi, 1640-1740, İstanbul Üniversitesi İktisat Fakültesi, Basılmamış Doçentlik Tezi, İstanbul 1965.

"Osmanlı Para Tarihinde Dünya Para ve Maden Hareketlerinin Yeri 1300-1750" Orta Doğu Teknik Üniversitesi Geliştirme Dergisi:1978 Özel Sayısı, Ankara, 1978, 2-93.

Sass, Benjamin, "The Silver and Billon Coins Minted at Constantinople Under Sultan Mahmud II (1223-1255 H.)" The American Numismatic Society Notes, 18 (1972), 167-175.

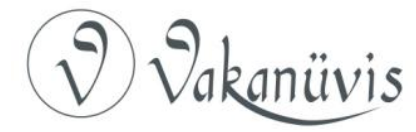


Süleyman Sûdî, Usûl-i Meskûkât-ı Osmaniyye ve Ecnebiyye, (yay. İbrahim Artuk, Cevriye Artuk), İstanbul 1982.

Şani-zâde Mehmed 'Ata'ullah Efendi, Şâni-zâde Târîhi [Osmanlı Târihi (1223-1237/1808-1821)], haz. Ziya Yılmazer, İstanbul 2008, c. 2. 


\begin{tabular}{|c|c|c|c|c|c|c|c|}
\hline \multicolumn{8}{|c|}{$\begin{array}{c}\text { Tablo I } \\
\begin{array}{r}\text { Maden Ocaklarından Darphaneye Gelen Gümüşü } \\
\text { (Hicrî 1203-1239/ Miladî 1788 }\end{array}\end{array}$} \\
\hline 1203 & 1204 & 1205 & 1206 & 1207 & 1208 & 1209 & 1210 \\
\hline $4.542 .638,5$ & $8.594 .224,4$ & $8.507 .263,4$ & $8.189 .824,938$ & $5.563 .981,443$ & $5.819 .829,489$ & $6.005 .190,882$ & $4.738 .397,019$ \\
\hline 1211 & 1212 & 1213 & 1214 & 1215 & 1216 & 1217 & 1218 \\
\hline $6.715 .255,959$ & $4.702 .658,211$ & $4.834 .132,383$ & $6.188 .586,384$ & $5.745 .799,101$ & $6.215 .037,72$ & $4.840 .735,596$ & $4.043 .674,23$ \\
\hline 1219 & 1220 & 1221 & 1222 & & \multicolumn{3}{|c|}{ Toplam (1203-1222/1788-1808) } \\
\hline $3.333 .942,681$ & $3.310 .823,418$ & Gümüş gelmemis & \$ $3.023 .280,591$ & & \multicolumn{3}{|c|}{$\begin{array}{c}104.915 .276,427 \\
(104.915,276 \mathrm{~kg} / 104,915 \text { ton })\end{array}$} \\
\hline 1223 & 1224 & 1225 & 1226 & 1227 & 1228 & 1229 & 1230 \\
\hline $3.178 .967,613$ & $3.208 .382,217$ & $3.272 .862,159$ & $4.097 .006,64$ & $4.022 .498,409$ & $4.464 .836,712$ & $4.167 .313,701$ & $3.894 .891,879$ \\
\hline 1231 & 1232 & 1233 & 1234 & 1235 & 1236 & 1237 & 1238 \\
\hline $3.142 .346,88$ & $3.642 .610,017$ & $3.503 .929,716$ & $2.808 .119,754$ & $2.327 .217,276$ & $2.275 .574,955$ & $2.597 .057,463$ & $2.304 .614,34$ \\
\hline 1239 & & & & & \multicolumn{3}{|c|}{\begin{tabular}{|l|} 
Toplam (1223-1239/1808-1824) \\
\end{tabular}} \\
\hline $2.021 .981,43$ & & & & & \multicolumn{3}{|c|}{ 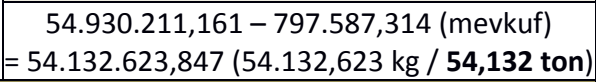 } \\
\hline \multicolumn{8}{|c|}{$\begin{array}{c}159.047 .900,274=159.047,9 \mathrm{~kg} \\
159,047 \text { ton }\end{array}$} \\
\hline
\end{tabular}

${ }^{47}$ HH.d, nr. 15352, vr. 1b-2a; Defterde dirhem olarak verilen miktarlar grama çevrilirken bir dirhem 3,207 gram olarak kabul edilmiştir.

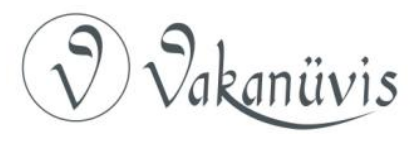



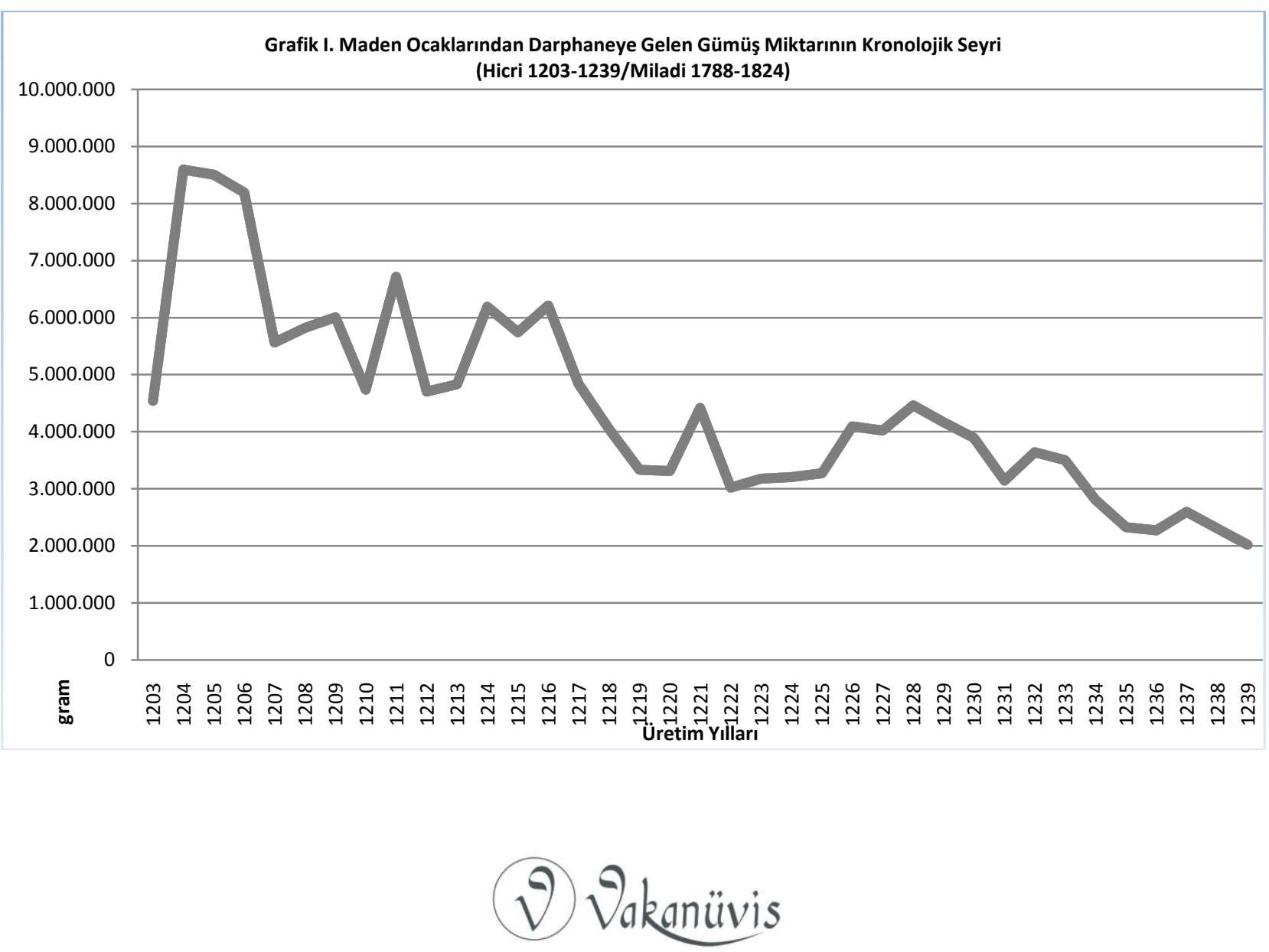


\begin{tabular}{|c|c|c|c|c|c|c|c|}
\hline \multicolumn{3}{|c|}{ Tablo II: Hicrî 1203-1239 (Miladî 1788-18 } & 4 dirhemlik kuruş & Cihâdiye (beş kuruşluk) & 3 dirhemlik kuruş & 2 dirhemlik kuruş & $\begin{array}{l}\text { Zolota ve çifte } \\
\text { zolota }\end{array}$ \\
\hline \multicolumn{3}{|c|}{ Basıldığı Dönem } & $\begin{array}{l}\text { Hicrî 1203'den itibaren } \\
\text { (Miladî 1789'dan } \\
\text { itibaren) }\end{array}$ & $\begin{array}{l}\text { Hicrî } 1225 \text { 'den itibaren } \\
\text { (Miladî } 1810 \text { 'dan } \\
\text { itibaren) }\end{array}$ & $\begin{array}{l}\text { Hicrî } 1225 \text { 'den itibaren } \\
\text { (Miladî } 1810 \text { 'dan } \\
\text { itibaren) }\end{array}$ & $\begin{array}{l}\text { Hicrî 1236'dan itibaren } \\
\text { (Miladî 1820-1821'den } \\
\text { itibaren) }\end{array}$ & $\begin{array}{l}\text { Hicrî } 1239 \text { 'dan } \\
\text { itibaren } \\
\text { (Miladî 1823- } \\
\text { 1824'den itibaren) }\end{array}$ \\
\hline \multirow{3}{*}{$\begin{array}{l}\text { Kullanılan } \\
\text { Gümüş } \\
\text { Miktarı }^{49}\end{array}$} & & $\begin{array}{r}\text { el toplam içindeki } \\
\text { oranı }\end{array}$ & $\% 66$ & $\% 8$ & $\% 21$ & $\% 3$ & $\% 2$ \\
\hline & & dirhem & 32.714 .461 & 3.989 .700 & 10.310 .039 & 1.621 .023 & 958.759 \\
\hline & & gram & 104.915 .276 & 12.794 .968 & 33.064 .295 & 5.198 .621 & 3.074 .740 \\
\hline \multicolumn{3}{|c|}{ Basılan Para Miktarı } & 14.913 .952 & $579.753,5$ & $6.266 .925,5$ & $1.475 .124,5$ & - \\
\hline \multicolumn{3}{|c|}{ Basılan Paranın Kuruş Karşılığı } & 14.913 .952 & $2.898 .766,5$ & $6.266 .925,5$ & $1.475 .124,5$ & 1.096 .286 \\
\hline \multirow{2}{*}{\multicolumn{2}{|c|}{$\begin{array}{ll}\begin{array}{l}\text { Elde } \\
\text { (kuruş) }\end{array} & \text { Edilen Kâr } \\
\end{array}$}} & Oranı & $\% 49$ & $\% 61$ & $\% 54$ & $\% 56$ & $\% 47$ \\
\hline & & Miktarı & $7.338 .820,5$ & 1.779 .226 & $3.356 .269,5$ & 823.311 & 519.931 \\
\hline \multicolumn{3}{|l|}{ Ayarı (Yüzde) } & 51 & 80 & $51^{50}$ & $51^{51}$ & 61 \\
\hline \multicolumn{3}{|c|}{ Vezni (dirhem) } & 4 & 8 & 3 & 2 & 1 \\
\hline \multicolumn{3}{|c|}{ Personel Ücreti (Her bin dirhemde) } & 70 & 70 & 70 & 70 & 70 \\
\hline \multicolumn{3}{|c|}{ Gümüşün Bir Dirheminin Bedeli (akçe) } & 27 & 33 & $33^{52}$ & $47^{53}$ & $71^{54}$ \\
\hline
\end{tabular}

\footnotetext{
${ }^{48} H H . d$, nr. 15352, vr. 1b, 2a.

${ }^{49}$ Dirhem grama çevrilirken 3,207 ile çarpılmış, ayrıca çok küçük küsuratlar yuvarlanmıştır.

${ }^{50}$ Defterde elli ayarında denilmekteyse de, hesaplamalar incelendiğinde elli bir ayarında olduğu tespit edilmiştir (HH.d, nr. 15352, vr. 2a).

${ }^{51}$ Defterde elli ayarında denilmekteyse de, hesaplamalar incelendiğinde elli bir ayarında olduğu tespit edilmiştir (HH.d, nr. 15352, vr. 2a).

${ }^{52}$ Defterde kullanılan gümüşün bedeli belirtilmiyorsa da, hesaplamalar yapıldığında bu rakam ortaya çıkmıştır (HH.d, nr. 15352, vr. 2a).

${ }^{53}$ Defterde gümüşün bedeli muhtelif olarak yazılmıştır. Ancak ortalama hesaplandığında bu rakam ortaya çıkar (HH.d, nr. 15352, vr. 2a).

${ }^{54}$ Defterde kullanılan gümüşün bedeli muhtelif olarak zikredilmektedir. Ancak bir ortalama belirlemek için hesaplama yapıldığında bu rakam ortaya çıkar (HH.d, nr. 15352, vr. 2a).
}

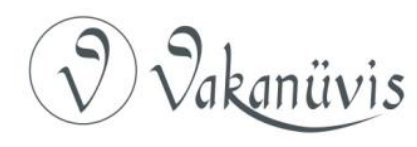




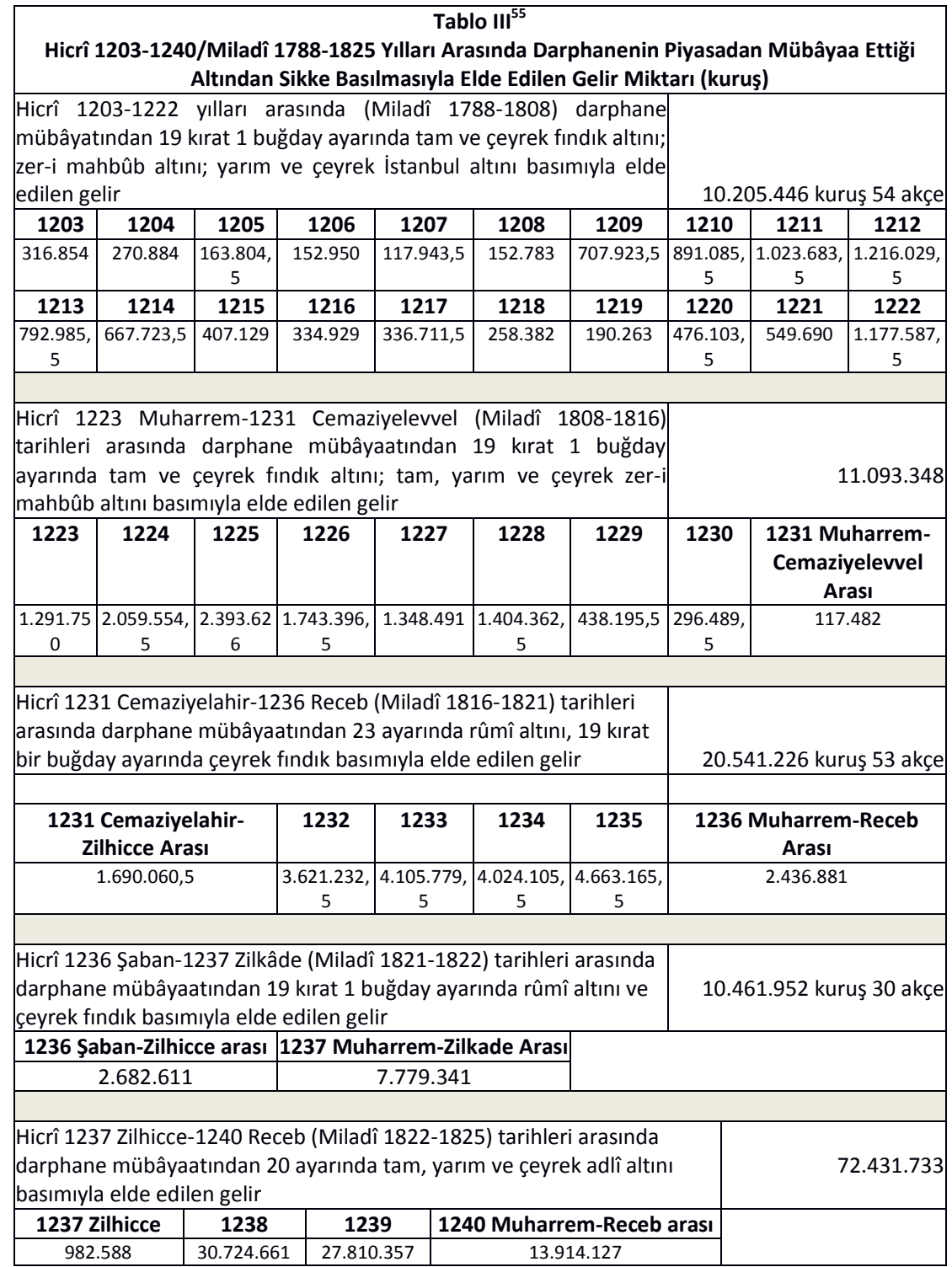

55 HH.d, nr. 15352, vr. 2b-3. Tabloda yıllık darp faizi rakamları verilirken akçeli küsuratlar yazılmamış, sadece genel toplamlarda akçeler gösterilmiştir. Bu nedenle genel toplamlar yıllık rakamların toplamından birkaç kuruş fazla olabilir. Bu durum bir hata sonucu değil, tablonun hazırlanışılla ilgili bir tercihin sonucudur.

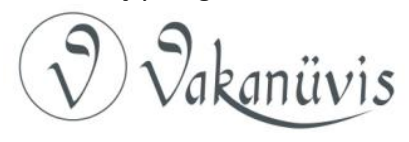



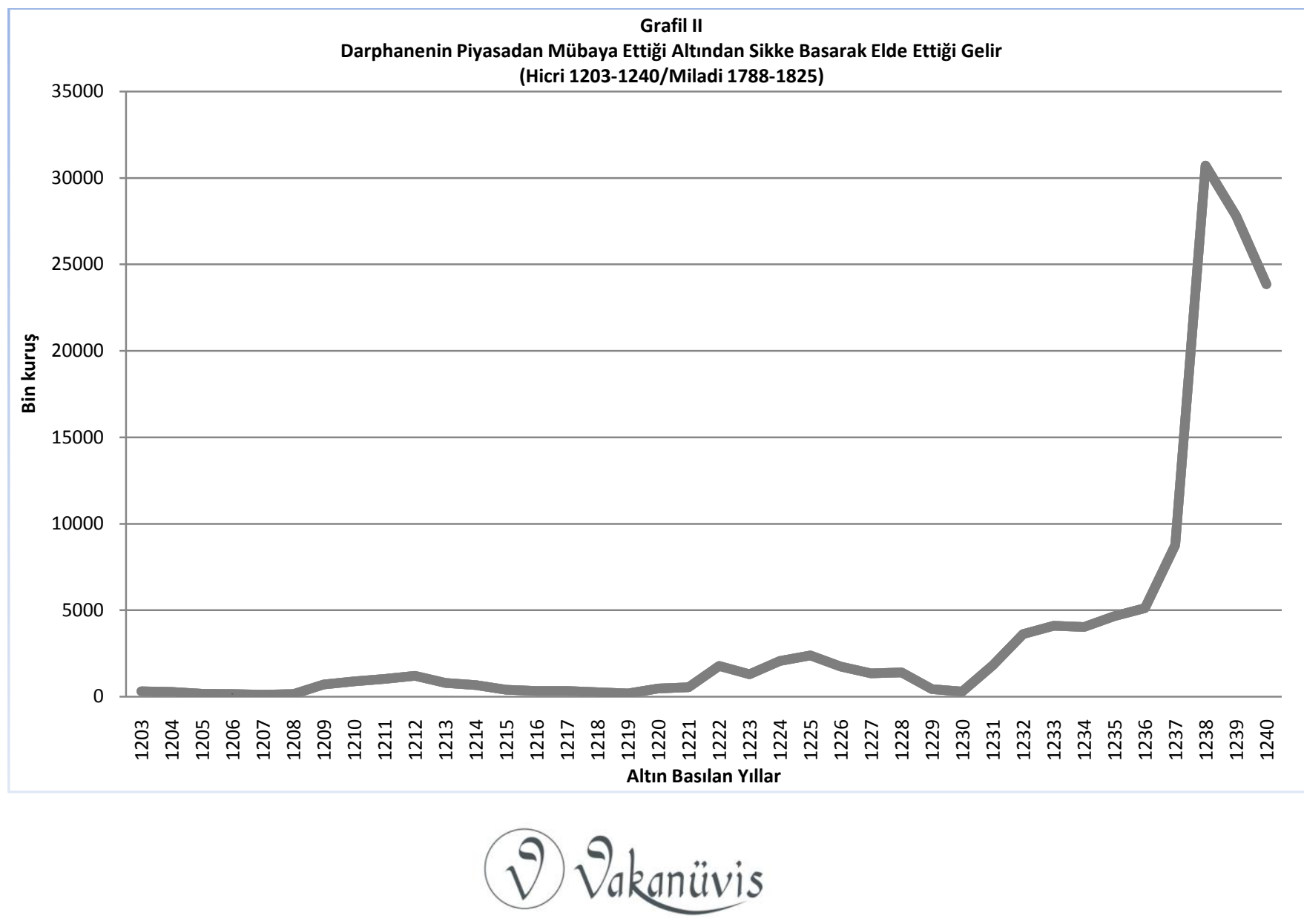


\begin{tabular}{|c|c|c|c|c|c|c|c|c|}
\hline \multicolumn{9}{|c|}{ TABLO IV } \\
\hline \multicolumn{6}{|c|}{ D.DRB.d, nr. 925'e Göre Piyasadan Satın Alınan Altından Sikke Darbının Ayrıntıları } & \multicolumn{3}{|c|}{ HH.d, nr. 15352'ye Göre Elde Edilen Kâr } \\
\hline \multirow[b]{2}{*}{ Hicrî Tarih } & \multirow[b]{2}{*}{$\begin{array}{c}\text { Halis Altın Olarak } \\
\text { Hammadde Miktarı } \\
\text { (dirhem) }\end{array}$} & \multirow[b]{2}{*}{$\begin{array}{c}\text { Basılan Altın } \\
\text { Miktarı } \\
\text { (zer-i mahbûb) }\end{array}$} & \multirow{2}{*}{$\begin{array}{c}\text { Basılan } \\
\text { Altının } \\
\text { Kuruş } \\
\text { Karşılığı }\end{array}$} & \multicolumn{2}{|c|}{ Elde Edilen Kâr } & \multirow{2}{*}{$\begin{array}{c}\text { Kâr } \\
\text { Miktarı } \\
\text { (kuruş) }\end{array}$} & \multirow{2}{*}{$\begin{array}{c}\text { Hata Miktarı } \\
\text { (kuruş) }\end{array}$} & \multirow{2}{*}{$\begin{array}{c}\text { Hata } \\
\text { Oranı }\end{array}$} \\
\hline & & & & Oran & $\begin{array}{l}\text { Miktar } \\
\text { (kuruş) }\end{array}$ & & & \\
\hline Rebiülahir 1222 & 210.604 & $350.097,5$ & 2.100 .582 & $\% 11,60$ & 243.649 & 123.649 & 120.000 & $\% 49,25$ \\
\hline $\begin{array}{l}\text { Cemaziyelevvel } \\
1222\end{array}$ & $133.720,5$ & 222.287 & $.291 .020,5$ & $\% 9,38$ & 121.108 & 121.110 & +2 & $\% 0,001$ \\
\hline $\begin{array}{l}\text { Cemaziyelahir } \\
1222\end{array}$ & $206.298,5$ & $342.940,5$ & 2.057 .646 & $\% 6,64$ & $136.666,5$ & $136.766,5$ & +100 & $\% 0,073$ \\
\hline Receb 1222 & & 286.590 & 1.620 .630 & $\% 8,12$ & 131.667 & 112.729 & 18.938 & $\% 14,38$ \\
\hline Şaban 1222 & 190.940 & 317.391 & 1.904 .350 & $\% 6,83$ & $130.225,5$ & $130.225,5$ & yok & Yok \\
\hline Ramazan 1222 & 197.025 & 327.655 & 1.965 .934 & $\% 6,11$ & $120.048,5$ & $120.048,5$ & yok & Yok \\
\hline Şevval 1222 & $197.104,5$ & 327.655 & $1.965 .936,5$ & $\% 6,11$ & 120.000 & 120.000 & yok & Yok \\
\hline Zilkâde 1222 & $171.503,5$ & 285.096 & 1.710 .576 & $\% 5,85$ & 100.000 & 100.000 & yok & Yok \\
\hline Zilhicce 1222 & 174.377 & 289.873 & 1.739 .246 & $\% 6,30$ & 109.588 & 100.125 & -9.463 & $\% 8,630$ \\
\hline \multicolumn{6}{|c|}{ D.DRB.MH, 250/23 ve 250/27'ye Göre Piyasadan Satın Alınan Altından Sikke Darbının Ayrıntıları } & \multicolumn{3}{|c|}{ HH.d, nr. 15352'ye Göre Elde Edilen Kâr } \\
\hline \multirow{2}{*}{$\begin{array}{l}\text { Cemaziyelevvel } \\
1237\end{array}$} & \multirow[b]{2}{*}{162.421} & $\begin{array}{l}220.000 \text { adet } \\
\text { rûmî altını } \\
\text { nısfiyyesi }\end{array}$ & \multirow[b]{2}{*}{3.250 .000} & \multirow[b]{2}{*}{$\% 20,54$} & \multirow[b]{2}{*}{667.574} & \multirow[b]{2}{*}{667.574} & \multirow[b]{2}{*}{ yok } & \multirow[b]{2}{*}{ yok } \\
\hline & & $\begin{array}{l}200.000 \text { adet } \\
\text { İstanbul altını } \\
\text { rûbiyyesi }\end{array}$ & & & & & & \\
\hline
\end{tabular}

